its merger with the Patent or Proprietary Medicine Act to become the Opium and Drugs Act of 1911. When Mackenzie King stated that opium's "baneful influences are too well known," he was drawing on nearly half-a-century of professional dialogue that transformed opium from a valuable medicine into an existential threat to the nation. Malleck's richly researched narrative may not have completely toppled arguments about the "racist roots" of Canada's drug laws; indeed, I was left wondering whether Malleck may have overstated his case somewhat, given the later clearly racialized enforcement of these new laws. Nevertheless, When Good Drugs Go Bad deepens our understanding of the connections that could be so easily drawn between the body, race, medicine and the nation in early twentieth century Canada.

Yvan Prkachin

Harvard University

\title{
NOTES
}

${ }^{1}$ W.L. Mackenzie King, "Report by W.L. Mackenzie King, C.M.G., on the Need for the Suppression of the Opium Traffic in Canada (Ottawa: Sessional Paper 36b, 1908)", 6.

Gada Mahrouse, Conflicted Commitments: Race, Privilege, and Power in Transnational Solidarity Activism (Kingston: McGill-Queen's University Press, 2014). 248pp. Paperback \$27.95.

This work addresses an important issue and practice in the contemporary context of global capitalist development. In particular it focuses on recent manifestations of transnational activism and solidarity of a certain type. This involves non-violent, largely witnessing, approaches in which activists from the global North journey to sites of conflict in the global South as a means of observing and supposedly shielding or protecting local communities, while sharing stories of injustice in their home locales.

That is the imagined intention anyway. As Gada Mahrouse effectively argues and illustrates in Conflicted Commitments, actual outcomes are often at odds with intentions and practices more complex and troubled than imagined or hoped for.

Mahrouse gives dedicated and developed attention and analysis to situations of struggle in Palestine and Iraq in the post-9/11 "eternal war on terror" context. The focus here-and this becomes a problem — is exclusively on non-violent, pacifist groups that operate largely within a human rights framework. These groups can generally (though not uniformly) be located within the terrain of global NGOs. The author examines racialized privilege (white, middle class activists) deployed, embodied, to raise awareness of acts of solidarity. The deployment of white, Western privilege actually re/produces structures and practices of colonialism and imperialism. 
Mahrouse builds her arguments through discussion of a range of relevant cases. These include the killing of Rachel Corrie and the James Loney capture affair, among others. Mahrouse notes that calls are put out by a variety of groups in conflict areas for activists to travel to support the communities, often as witnesses or observers. Among the groups making such calls for activists to join them are Oaxaca Solidarity Network (OSN), International Solidarity Movement (ISM), Peace Brigades International (PBI), and Project Accompaniment and Solidarity (PASC). The appeals are often explicitly for activists from specific areas, Canada and the US, for example, rather than simply for any international activists.

Along the way Mahrouse lays out the problems and contradictions of these approaches to activism. The focus is on the positionality of the activists and elatedly the connection to hegemonic readings of these actions in the imperial centres. The author's stated claims in writing the book are to identify "the barriers, contradictions, and concerns" that emerge in transnational solidarity activism in order "to inform anti-racist and de-colonial practices" (5). Mahrouse seeks to reflect on ethics and pragmatics of social justice strategies in an increasingly transnational context (5).

Yet the focus of the narrative, on a particular type of non-violent action, is not suited to meet these aspirations. Mahrouse could have but did not look at and compare explicitly anti-imperialist groups, groups that support armed struggle, or direct action (nonviolent) activists. There are groups like the International League for Peoples Struggle, for example, that do much solidarity work directly with communities in struggle but who take a much different approach and are connected to and viewed by local groups much differently (more directly or relatedly) than the groups examined in this text. The examination of alternative, anti-imperialist movements could address a key question posed by Mahrouse's stated influences, Inderpal Grewal and Caren Kaplan, and their proposal that "international social movements (such as peace movements and international women's groups) be examined by placing front and centre the inequalities in living standards between nations, unequal access to resources, the legacy of colonialism, and international trade (171). There are transnational solidarity movements that pursue precisely this approach. Yet they are glaringly absent from this study and analysis.

The need to expand the view to take into account other forms of solidarity organizing, strategies, and tactics (and associated perspectives or theories) is raised as well in addressing a key question for Mahrouse: how race works through situations and groups. Mahrouse suggests that "race works similarly across different activist strategies and groups" (13), and she seeks to answer how. Yet this similarity might result from or be restricted to the similar type of activism and approach to activism examined in this work (and the similar journeying participants). Other approaches and perspectives might well give rise to other processes, outcomes, and expressions of identity and effects. These can offer different class features as well 
in terms of who is doing the travelling for what reasons. This discussion is important in pointing out liberal assumptions about the rational, reasonable, and communicative character of the colonial and imperial state, at least when talking about white, middle strata citizens. Yet it misrepresents the state in capitalism.

As one more central criticism of the book, except in one particular and interesting instance in looking at the perspectives of Palestinians, the analysis lacks a real engagement with on-the-ground views, strategies, and tactics of communities in struggle themselves and their sense of how the observer-witness activism fits into their own broader efforts. One of the interesting observations made by Gahrouse was that in interviews with Palestinian organizers, no distinction was made between activists and tourists when speaking of Westerners who they interacted with. That is, respondents referred to both explicit activists who travelled to act as observer/witnesses, and tourists who may have taken part in a demonstration both as tourists. And the term tourist was used even when questions were posed about activists.

Yet there are too few of these insights from organizers rooted in community conflicts and the reader wishes more was heard from their perspective. It is a strange gap given the book's stated concerns with imperialism, identity, and agency. As a reader it is less interesting to hear about the ways in which privileged non-violent witnesses rationalize (and contextualize) their actions than in how local organizers understand this type of action and in broader repertoires of resistance.

Again the interviews, and in this case the extremely limited number of people actually interviewed, seriously constrain the analysis. The author only interviewed four Palestinians on the issues. While claiming that the interest in doing the interviews was largely examining narrative frameworks it remains that the approach taken leaves the reader wanting more (in depth, and detail). This is true both in terms of the numbers of people offering thoughts, reflections, and criticisms and in terms of the nature and details of their perspectives.

In a period in which capital and states (in industrial production, trade deals, legal conventions, security assemblages, wars and occupations, etc.) are increasingly acting on global levels, it is important to analyse and understand activities and alliances undertaken by non-elites, the exploited, and the oppressed, in developing their own forms of transnational counter-power. Much concern has been raised about the possibilities, promise, and problems of transnational activism and solidarity, perhaps most extensively in discussions of transnational labour organizing for example.

Still, it is especially welcome and exciting (and necessary) to encounter a work such as Conflicted Commitments, which seeks to analyze and learn from transnational activism in some of the pressing contexts of social struggle in the present period. It is also encouraging to see an explicit focus on issues of racialization and privilege in relations between activists in the global North and the global South. The book raises important questions about activist strategies and tactics, social jus- 
tice politics, and the nuanced development of capitalism in the context of neoliberal globalism. It is a worthwhile read despite its limitations.

Jeff Shantz

Kwantlen Polytechnic University

\section{Scott Laderman, Empire in Waves: A Political History of Surfing (Berkeley: University of California Press, 2014). 256pp. Hardcover $\$ 65.00$.}

The serious study — and critique_ - of surfing as a social phenomenon has been a long time coming. Not that surfing hasn't been written about extensively over the last century - it has, but it has been limited to the confines of popular culture. It is only in the last decade or so that an emerging literature, often referred to as critical surf studies, has begun to slowly show itself. Viewing surfing through the lens of various social science frameworks, scholars are analyzing how the sport and lifestyle of surfing has influenced the modern world across a broad spectrum of sociopolitical realities. Empire in Waves by Scott Laderman is one of the most important contributions to this literature so far.

If there are such things as master narratives in popular surf culture (and as a surfer I believe unequivocally that there are), they are rooted not only in the language of the pursuit of personal pleasure and even spiritual enlightenment, but also in the problematic language of "discovery" and "exploration" while that culture simultaneously imagined itself as immune to politics. For Laderman this is more appropriately conceived in terms of empire.

Laderman begins appropriately with what he characterizes as the appropriation of Native Hawaiian culture during the overthrow era of Hawaii, calling it the "Americanization" of surfing. The way this history has invariably been portrayed in popular surf cultural production is as whimsical tales about ancient Hawaii's "gift" to the modern world. Given that modern surf culture does trace its genesis to Hawaii, this was, he argues, the beginning of surfing's complicated relationship with imperialism. Devoting the entire first chapter to surf culture's otherwise highly romanticized founding myth, Laderman links surfing with American imperialism in the fin de siècle era, revealing how surfing was initially employed as a tool of colonization in Hawaii and the United States' growing need to shore up its military presence in the South Pacific.

Fully understanding modern surf culture's emergence from post-overthrow Hawaii requires a detailed analysis of Alexander Hume Ford, which Laderman faithfully executes in the first chapter. Ford is usually uncritically celebrated as having engineered the genesis of modern surf culture, but it is also well known that Ford made it his personal project to use surfing as a marketing tool to build the Hawaiian tourist industry - now safely in American hands-and Laderman examines this thoroughly. Where he veers off from popular histories is by highlighting 